\title{
Eñes
}

\section{Break-Even Analysis of All-Solid-State Batteries with Li-Garnet Solid Electrolytes}

Cite This: ACS Energy Lett. 2021, 6, 2202-2207

Read Online

$\mathrm{P}$ resently, replacement of liquid electrolytes by their solid-state counterparts is pursued as a compelling way to improve energy densities, safety, and the cycle life of conventional Li-ion batteries (LIBs). ${ }^{1}$ Toward this goal, rechargeable battery technologies based on solid-state electrolytes (SSEs), such as Li garnets, ${ }^{2-8}$ LISICON $\left(\mathrm{Li}_{14} \mathrm{ZnGe}_{4} \mathrm{O}_{16}\right)$, thio-LISICON $\left(\mathrm{Li}_{4-x} \mathrm{M}_{1-x} \mathrm{P}_{x} \mathrm{~S}_{4} \quad(\mathrm{M}=\mathrm{Ge}, \mathrm{Si}),{ }^{9,10}\right.$ $\left.\mathrm{Li}_{10} \mathrm{GeP}_{2} \mathrm{~S}_{12}\right),{ }^{11} \mathrm{Li}_{2} \mathrm{~S}-\mathrm{P}_{2} \mathrm{~S}_{5}$ glass, ${ }^{12}{ }^{1} \mathrm{Li}_{7} \mathrm{P}_{3} \mathrm{~S}_{11}$ glass-ceramic, ${ }^{13}$ argyrodites $\mathrm{Li}_{6} \mathrm{PS}_{5} \mathrm{X}(\mathrm{X}=\mathrm{Cl}, \mathrm{Br}, \mathrm{I}){ }^{14,15}$ perovskites, ${ }^{16,17}$ and antiperovskites, ${ }^{18}$ have come into the research spotlight. In particular, batteries that employ the garnet-type $\mathrm{Li}_{7} \mathrm{La}_{3} \mathrm{Zr}_{2} \mathrm{O}_{12}$ (LLZO) SSE harness numerous advantages, such as high ionic conductivity of up to $1 \mathrm{mS} \mathrm{cm}$ at room temperature (RT), ${ }^{2,3,19-21}$ chemical stability with metallic lithium, ${ }^{2,23}$ and low electronic conductivities of ca. $10^{-8} \mathrm{~S} \mathrm{~cm}^{-1}$ (RT). ${ }^{24}$ Besides, LLZO has a wide electrochemical window $(>6 \mathrm{~V}$ vs $\mathrm{Li} / \mathrm{Li}^{+}$obtained in the experimental operation ${ }^{25,26}$ and $\sim 3 \mathrm{~V}$ from computational analyses ${ }^{27}$ ), allowing for employment of high-voltage cathode materials, unlike other Li-ion solid-state conductors, such as those based on sulfides. ${ }^{28,29}$

Despite numerous studies on LLZO-based cells, ${ }^{26,29-36}$ there is a lack of research on designing cells that possess practically relevant gravimetric and volumetric energy densities of $>250 \mathrm{Wh} \mathrm{kg}^{-1}$ and $700 \mathrm{Wh} \mathrm{L} \mathrm{L}^{-1}$, respectively. The vast majority of laboratory research in this area is conducted on millimeter-thick LLZO pellets, as they are readily produced by well-established high-temperature solid-state synthesis and are convenient for assembling symmetric and full cells for studying the performance of the SSE itself, as well its combinations with various electrode materials. Notwithstanding the rapidly improving performance of these cells, such thick pellets of SSEs (see Table S1) cannot be used in commercial solid-state batteries (SSBs) due to their high mass and hence the reduced and impractical overall energy density of the battery. Furthermore, tests with mm-thick pellets may lead to incorrect conclusions about the achievable performance of much thinner SSE membranes $(20-50 \mu \mathrm{m})$, eventually required for commercial batteries, namely with regard to cycling stability and critical current density of the SSE. LLZO membranes are very brittle $\mathrm{e}^{37-40}$ and prone to the formation of cracks, which in turn results in the formation of Li-metal dendrites upon battery operation. ${ }^{41-43}$ The other disparity with practical requirements stems from the common practice of using small areal capacities of cathodes in laboratory cells. ${ }^{44-52}$ The typical performance of such thin electrodes $\left(<1 \mathrm{mAh} \mathrm{cm}^{-2}\right)$ may not reach required areal capacities $\left(>3.5 \mathrm{mAh} \mathrm{cm}^{-2}\right)$ at higher cathode mass loadings without proper engineering of interfaces and solidstate ionic transport.

In this Viewpoint, we comprehensively assess gravimetric and volumetric energy densities of Li-garnet SSBs, with the aim to aid further development and commercialization of this technology. In the analysis, we employ a battery configuration consisting of a metallic lithium anode, LLZO solid electrolyte, and LLZO composite cathode, as shown in Figure 1. The cathodic areal capacity and the thickness of the LLZO solid electrolyte are selected as two major variables of importance for the practical development of Li-garnet SSBs, for which the respective minimal and maximal values (break-even points) required to reach the energy density of conventional Li-ion batteries (ca. 250 and $700 \mathrm{Wh} \mathrm{kg}^{-1}$ ) were determined. Another factor that hinders the commercial deployment of Li-garnet SSBs is finding a minimal yet sufficient LLZO content in the composite cathodes, and we outline these practical limits for $\mathrm{LiCoO}_{2}$ (LCO), $\mathrm{LiNi}_{0.33} \mathrm{Mn}_{0.33} \mathrm{Co}_{0.33} \mathrm{O}_{2}$ (NMC111), $\mathrm{LiFePO}_{4}$ (LFP), $\mathrm{LiNi}_{0.5} \mathrm{Mn}_{1.5} \mathrm{O}_{4}$ (LMNO), $\mathrm{FeF}_{3}$, and sulfur composite cathodes.

Figure 2 shows the energy density of an LLZO battery comprising a $\mathrm{LCO}$ cathode and $\mathrm{Li}$ anode vs the two key parameters identified as most relevant for maximizing the energy density: (i) the thickness of the LLZO dense layer separating the cathode and $\mathrm{Li}$ anode layers and (ii) the areal capacity of the cathode layer. The impact of varying the thickness of the Li metal anode is discussed later; for now, it is fixed that the $\mathrm{Li}$ anode areal capacity in the discharge state corresponds to $20 \%$ of the cathode's areal capacity. Hence, for cathodic areal capacities of 1,3 , and $5 \mathrm{mAh} \mathrm{cm}^{-2}, \mathrm{Li}$ anode thickness equals 1,3 , and $5 \mu \mathrm{m}$, accordingly. In this configuration, ca. $83 \%$ of the total lithium amount (in both electrodes) should pass through the LLZO electrolyte upon the first charge of the battery. Aiming to assess the energy density of Li-garnet SSBs as realistically as possible, we considered the conventional composition of cathodes based on $95 \mathrm{wt} \%$ of cathode active material, $3 \mathrm{wt} \%$ of carbon black, and 2 wt\% of the PVDF binder. Additional parameters that are not

Received: March 30, 2021

Accepted: April 9, 2021

Published: May 18, 2021 
a
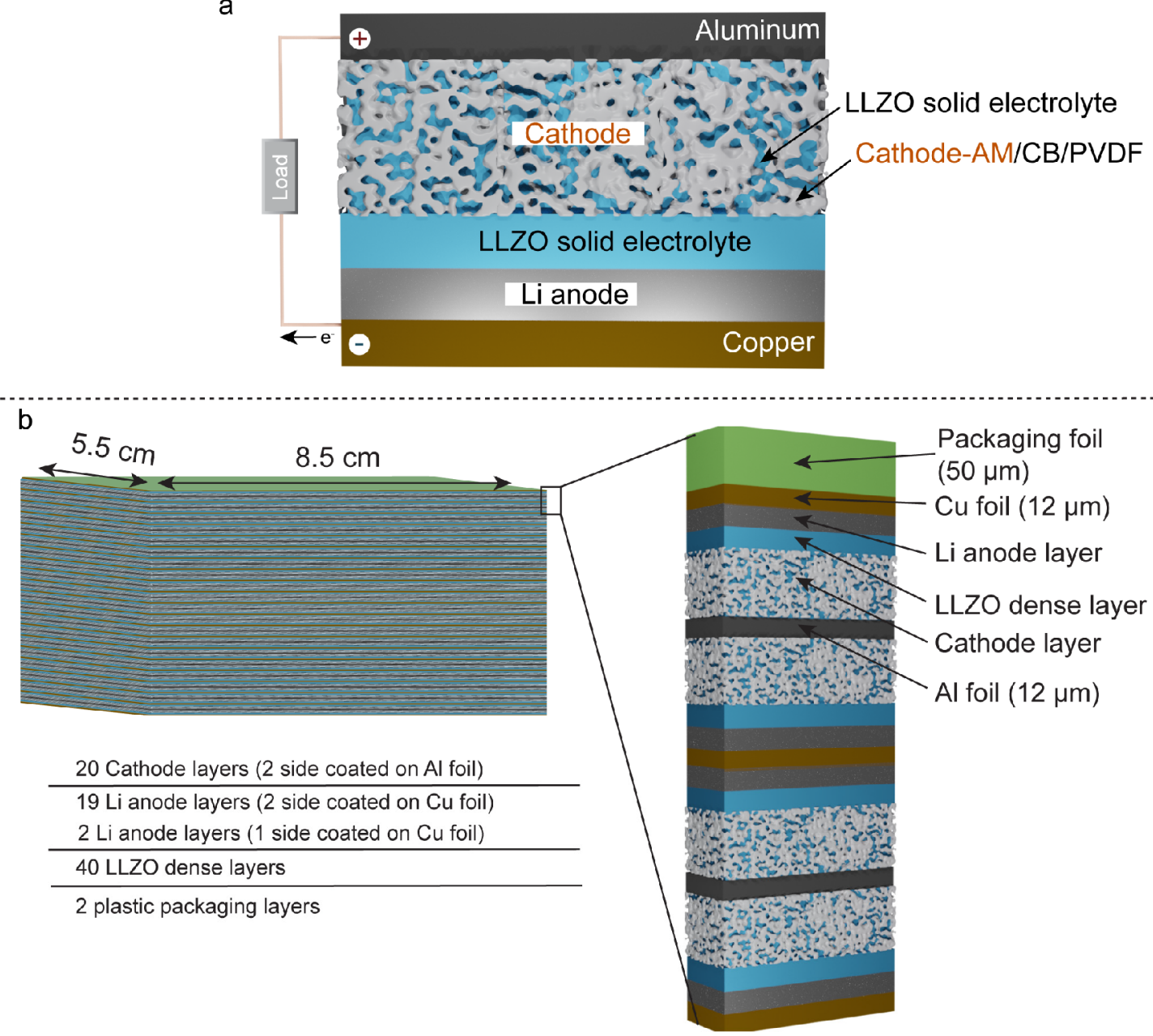

Figure 1. Schematics of the cell (a) and a battery (b) considered in this work for assessing the energy densities of Li-garnet SSBs. CathodeAM is cathode active material. CB is carbon black. PVDF is polyvinylidene fluoride binder.

shown in Figure 2 include the thickness of $\mathrm{Cu}$ and $\mathrm{Al}$ foils and the thickness of pouch $\mathrm{Al}$ foil, and they were kept constant (see Table S2 for details).

The achievable gravimetric and volumetric energy densities were calculated from active material loading, active material utilization, assumed average cell voltage of $3.9 \mathrm{~V}$, and total weight or volume of all cell components. The cell volume is calculated in the fully discharged state, which is the state in which the battery would be assembled. No kinetic or transport limitations are used in these calculations. Additionally, $100 \%$ of active material cathode utilization is assumed. A total of 40 cathode/electrolyte/anode layers was assumed (Figure 1). It should also be emphasized that employment of high areal capacities of $>1 \mathrm{mAh} \mathrm{cm}^{-2}$ can be practically achieved only at pressures suitable to prevent the formation of voids/cavities at the $\mathrm{LLZO} / \mathrm{Li}$ interface. ${ }^{53-56}$ Utilization of pressure unavoidably results in added non-active components and hence decreases the energy density. Owing to the uncertainties as to the required and optimal pressures and thus the practical embodiment of this requirement, we omitted this parameter from the calculation of the energy density. Additionally, we note that, although the employment of the LLZO SSE allows for the design of high-voltage bipolar stacked batteries and thus further increasing their energy density, ${ }^{57-59}$ the stacking of multiple cells within a single package has thus far been proven challenging. ${ }^{60}$ Consequently, in this work, a conventional (monopolar) battery configuration that is employed in the current design of liquid LIBs is considered.

We first consider the LCO cathode with a porosity of $30 \%$, assuming that the pores of the electrolyte are filled by three different electrolytes: $1 \mathrm{M} \mathrm{LiPF}_{6}$ in ethylene carbonate/ dimethyl carbonate (EC/DMC) conventional electrolyte, 0.3 $M$ LiTFSI (lithium bis(trifluoromethanesulfonyl)imide) in PY14TFSI (N-butyl- $N$-methyl-pyrrolidiniumbis(trifluoromethanesulfonyl)imide) ionic liquid electrolyte, or LLZO SSE. In all cases, no unoccupied pore volume is assumed to exist. In Figure 2, the energy density of the battery is plotted vs cathode capacity and LLZO thickness. The LLZO thicknesses that allow the cell to attain the energy density of a conventional LIB (250 $\mathrm{Wh} \mathrm{kg}^{-1}$ and $700 \mathrm{Wh} \mathrm{L}^{-1}$ ) at a given cathode areal capacity are identified. Such a value is referred to as the break-even thickness, in analogy to the break-even point in economics, i.e., the point at which total cost and total revenue are equal.

The break-even thicknesses of the LLZO electrolyte for three different scenarios with respect to the gravimetric energy density are summarized in Figure $3 a$ as a function of cathode areal capacity. As follows from Figure $3 a$, in the case of conventional liquid electrolyte in the cathode pores, the breakeven LLZO thickness ranges from 31 to $51 \mu \mathrm{m}$ for $3.5 \mathrm{mAh}$ $\mathrm{cm}^{-2}$ and $5 \mathrm{~mA} \mathrm{~cm}{ }^{-2}$, accordingly. A similar break-even thickness range of $30-50 \mu \mathrm{m}$ is obtained with ionic liquid 

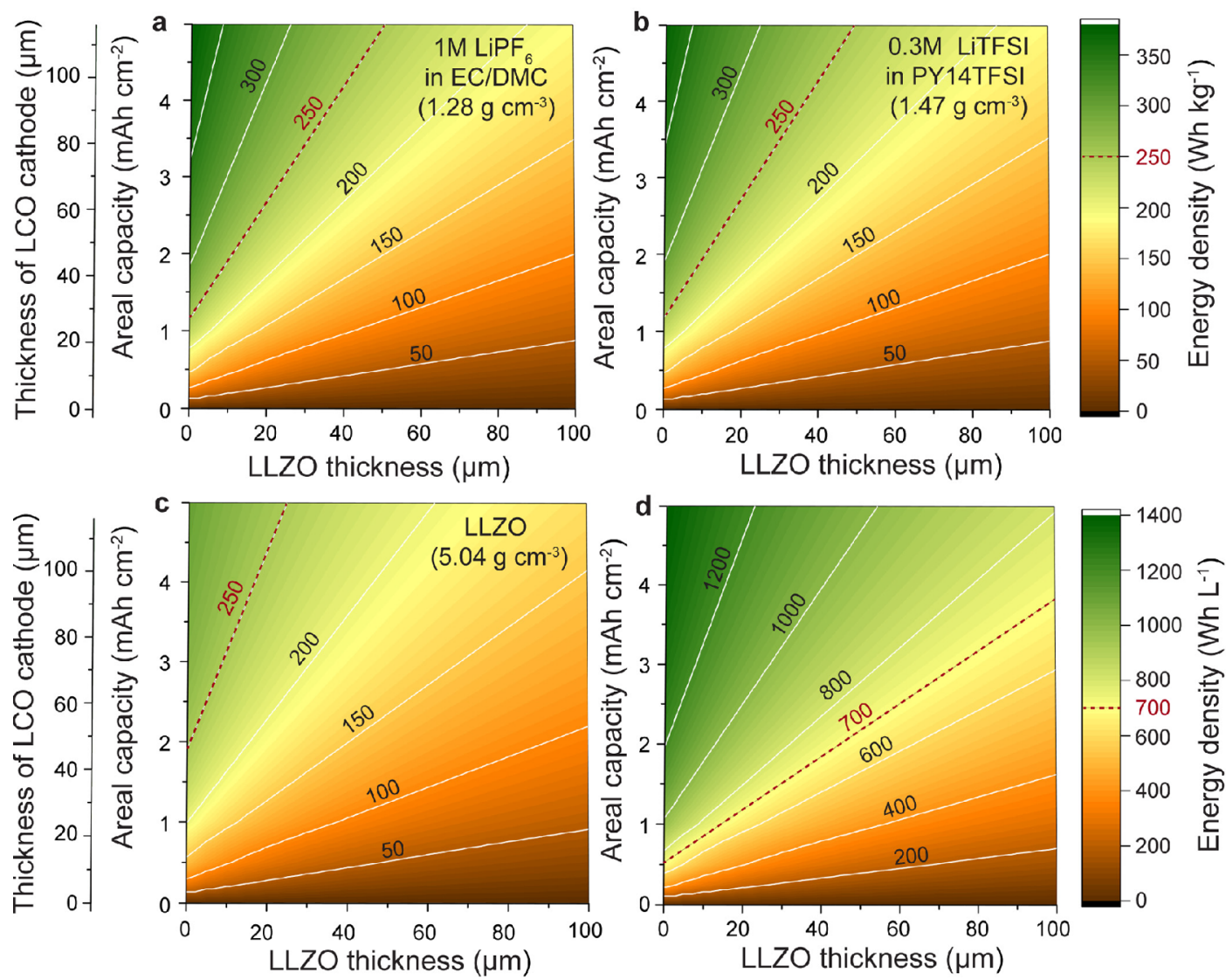

Figure 2. $(\mathrm{a}-\mathrm{c})$ Calculated gravimetric energy density of Li/LCO batteries vs cathode areal capacity and LLZO thickness. Batteries comprise $1 \mathrm{M} \mathrm{LiPF}_{6}$ in EC/DMC (a), 0.3 M LiTFSI in PY14TFSI (b), and LLZO (c) electrolytes in the LCO cathode. (d) Volumetric energy density of $\mathrm{Li} / \mathrm{LCO}$ batteries vs cathode areal capacity and LLZO thickness.
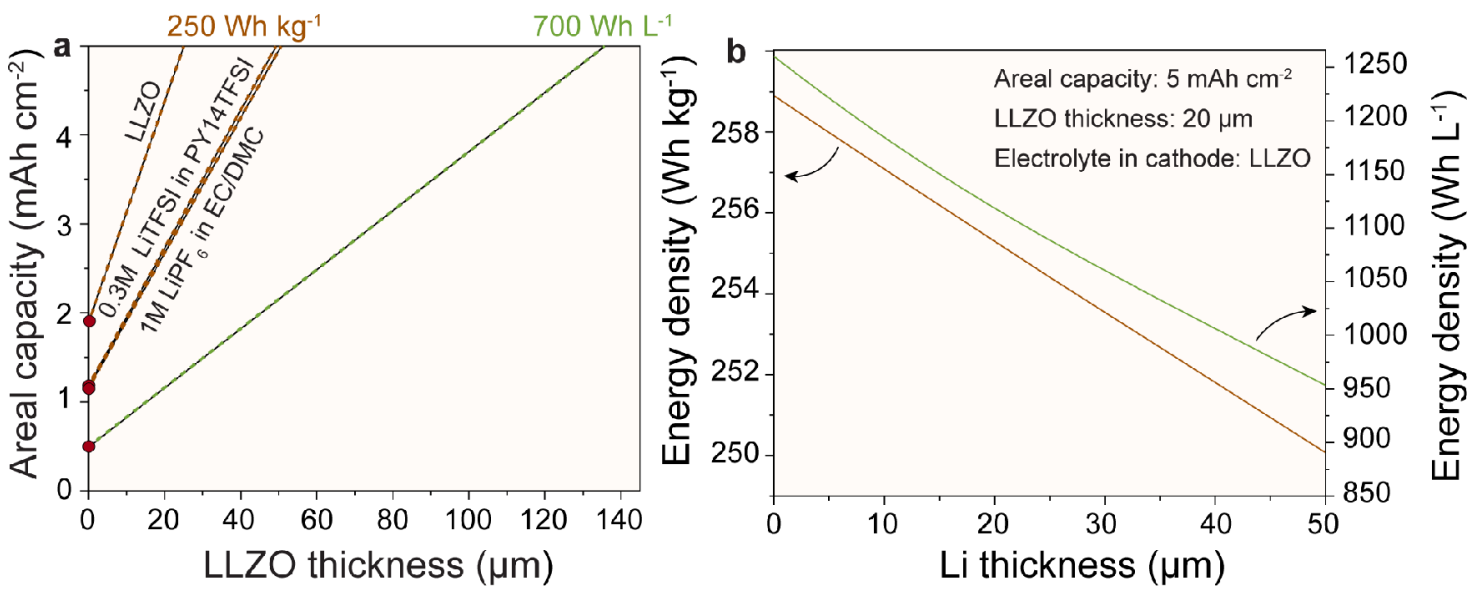

Figure 3. (a) Gravimetric and volumetric break-even thicknesses of LLZO electrolyte vs cathode area capacity for garnet-type Li metal batteries comprising LCO cathode impregnated with $1 \mathrm{M} \mathrm{LiPF}_{6}$ in EC/DMC, $0.3 \mathrm{M}$ LiTFSI in PY14TFSI, and LLZO electrolytes. (b) Change of gravimetric and volumetric energy densities of LCO-based Li-garnet SSBs vs Li anode thickness at fixed cathode areal capacity of $5 \mathrm{mAh} \mathrm{cm}{ }^{-2}$ and LLZO thickness of $20 \mu \mathrm{m}$.

electrolyte as pore-filler. However, in the case of an all-solidstate system comprising LLZO electrolyte only, much lower thicknesses of $13-25 \mu \mathrm{m}$ must be used in order to reach the same energy density of $250 \mathrm{Wh} \mathrm{kg}^{-1}$. The volumetric energy density values are identical for batteries composed of either liquid or solid electrolytes, as the volume of batteries remains unchanged for all used electrolytes. Consequently, break-even LLZO thicknesses are identical for all three considered cases and equal $90-136 \mu \mathrm{m}$ for $3.5 \mathrm{mAh} \mathrm{cm}^{-2}$ and $5 \mathrm{~mA} \mathrm{~cm}{ }^{-2}$, accordingly.

Interestingly, assuming that one can apply an infinitely thin LLZO layer, the break-even cathode areal capacity was found to be $1.16,1.18$, and $1.89 \mathrm{mAh} \mathrm{cm}^{-2}$ for the cells comprising carbonate-based, ionic liquid, and LLZO electrolytes in cathode pores. When comparing the same calculations for volumetric energy density, an areal capacity of $0.49 \mathrm{mAh} \mathrm{cm}{ }^{-2}$ was found to be the break-even value. Of note, higher Li excess 
has only a modest effect on gravimetric energy densities. For example, when the $\mathrm{Li}$ anode thickness was multiplied by 10 , the gravimetric break-even LLZO thickness at a cathode areal capacity of $5 \mathrm{mAh} \mathrm{cm}^{-2}$ shifted from 24.6 to $20.0 \mu \mathrm{m}$, while the volumetric break-even thickness changed significantly from 135.7 to $92.1 \mu \mathrm{m}$ (Figure S1). At the same time, at a fixed cathode areal capacity of $5 \mathrm{mAh} \mathrm{cm} \mathrm{cm}^{-2}$ and LLZO thickness of $20 \mu \mathrm{m}$, the gravimetric energy density decreased from $258 \mathrm{Wh}$ $\mathrm{kg}^{-1}$ to only $250 \mathrm{Wh} \mathrm{kg}^{-1}$ (Figure $3 \mathrm{~b}$ ). On the contrary, a significant reduction of the volumetric energy density (from 1220 to $953 \mathrm{Wh} \mathrm{L}^{-1}$ ) was found for a 10 -times thicker $\mathrm{Li}$ anode $(50 \mu \mathrm{m}$ instead of $5 \mu \mathrm{m})$.

Next, we analyzed the dependence of volumetric and gravimetric energy densities of solid-state LLZO cells on the porosity of the cathodes (LLZO electrolyte content) based on LCO, NMC111, LFP, LMNO, $\mathrm{FeF}_{3}$, and $\mathrm{S}$ cathode active materials. Figures $\mathrm{S} 2-\mathrm{S} 7$ evidence that, upon an increase of LLZO content in a composite cathode, a higher areal capacity and a lower LLZO membrane thickness should be used to attain the same energy density values $\left(250 \mathrm{Wh} \mathrm{kg}^{-1}\right.$ and 700 Wh $\mathrm{L}^{-1}$ ). Interestingly, assuming that the battery can be fabricated with a LLZO thickness as low as $10 \mu \mathrm{m}$ and a high areal capacity of $5 \mathrm{mAh} \mathrm{cm}{ }^{-2}$, solid composite cathodes cannot have more than $40 \%, 46 \%, 40 \%, 56 \%, 79 \%$, and $89 \%$ LLZO (by weight) to result in gravimetric energy densities that at least match those of conventional Li-ion batteries for LCO, NMC111, LFP, LMNO, $\mathrm{FeF}_{3}$, and $\mathrm{S}$ cathodes, respectively. With regard to the volumetric energy density of $700 \mathrm{Wh} \mathrm{kg}^{-1}$, the maximum permitted LLZO volume content lies at $66 \%$, $68 \%, 45 \%, 71 \%, 83 \%$, and $84 \%$ for LCO, NMC, LFP, LMNP, $\mathrm{FeF}_{3}$, and $\mathrm{S}$ cathodes, respectively. It should be noted that the higher the thickness of LLZO, the lower should be the content of LLZO in the composite electrode. For example, Table S3 presents the recommended maximum LLZO content for various cathode active materials to achieve an energy density of $250 \mathrm{Wh} \mathrm{kg}^{-1}$ for 10 - and $20-\mu$ m-thick LLZO layers. Importantly, the data on high-capacity conversion-type cathodes such as $\mathrm{FeF}_{3}$ and $\mathrm{S}$ point to the fact that, hypothetically, up to $75-89 \%$ of LLZO weight content can be used in their electrodes. In the case of high-voltage intercalation-type LMNO cathodes, the maximum allowable LLZO volume content ranges from $53 \%$ to $56 \%$. On the contrary, the LLZO content in conventional intercalation-type cathodes such as LCO, NMC, and LFP should not exceed 33$46 \%$.

Summary and Outlook. While the literature on Li-garnet solid-state batteries has been flourishing in recent years, the development of their commercially competitive prototypes lags far behind. We reiterate that commonly reported tests on LLZO-based batteries as well as symmetrical cells employ mmthick pellets and therefore do not provide practically relevant information on the achievable cycling stability and critical current density of $\mu$ m-thin LLZO solid-state electrolytes required in commercially viable solid-state battery architectures. In this context, we encourage researchers working on $\mathrm{Li}$ garnet solid-state batteries to focus investigations on LLZO membranes with a small thickness of $20-50 \mu \mathrm{m}$, which will allow discerning the entirety of truly relevant technical challenges at early stages, be it the membrane itself (synthesis, properties, interface engineering) or a suitable battery design and manufacturing process.

We further note that the employment of cathodes with a high areal capacity of $>3.5 \mathrm{mAh} \mathrm{cm}^{-2}$ is imperative for reaching high gravimetric and volumetric energy densities of $250 \mathrm{Wh} \mathrm{kg}^{-1}$ and $700 \mathrm{Wh} \mathrm{L}^{-1}$. Thus far, the laboratory LLZObased cells utilized electrodes that have a very low areal capacity (on average $0.5-1 \mathrm{mAh} \mathrm{cm}^{-2}$ ). As with the LLZO thickness, we recommend using thicker electrodes for early identification of the most relevant factors hampering the achievable energy and power densities and to outline cathodematerial-specific research efforts.

We showed the maximal content of LLZO within the pores of a composite cathode that still permits matching the energy densities of the state-of-the-art Li-ion batteries $\left(250 \mathrm{Wh} \mathrm{kg}^{-1}\right)$, as discussed for LCO, NMC111, LFP, LMNO, $\mathrm{FeF}_{3}$, and sulfur composite cathodes. We also emphasize that minimization of the Li metal anode thickness in the Li-garnet batteries is not critical for their gravimetric energy density. The employment of thick commercial $\mathrm{Li} / \mathrm{Cu}$ foils with a $\mathrm{Li}$ thickness of ca. $50 \mu \mathrm{m}$ appears to be a practically viable approach. For instance, upon increasing the Li thickness from 5 to $50 \mu \mathrm{m}$, the gravimetric energy density decreases only slightly, from 259 to $250 \mathrm{Wh} \mathrm{kg}^{-1}$ (at a fixed cathode areal capacity of $5 \mathrm{mAh} \mathrm{cm}^{-2}$ and LLZO thickness of $20 \mu \mathrm{m}$ ). At the same time, the volumetric energy density is significantly reduced by ca. $306 \mathrm{Wh} \mathrm{L}^{-1}$ (from 1220 to $953 \mathrm{Wh} \mathrm{L}^{-1}$ ).

Kostiantyn V. Kravchyk orcid.org/0000-0001-6149-193X

Faruk Okur

Maksym V. Kovalenko @ orcid.org/0000-0002-6396-8938

\section{ASSOCIATED CONTENT}

\section{Supporting Information}

The Supporting Information is available free of charge at https://pubs.acs.org/doi/10.1021/acsenergylett.1c00672.

Table S1, comparison of reported Li-garnet solid-state battery compositions; Table S2, parameters used in the energy density calculations; Table S3, recommended maximal LLZO content in cathodes; Figures S1-S7, calculated gravimetric and volumetric energy densities of batteries (PDF)

\section{AUTHOR INFORMATION}

Complete contact information is available at: https://pubs.acs.org/10.1021/acsenergylett.1c00672

\section{Notes}

Views expressed in this Viewpoint are those of the authors and not necessarily the views of the ACS.

The authors declare no competing financial interest.

\section{ACKNOWLEDGMENTS}

This research is part of the activities of the joint EmpaFraunhofer ICS project "IE4B", which is financially supported under the ICON funding scheme.

\section{REFERENCES}

(1) Albertus, P.; Anandan, V.; Ban, C.; Balsara, N.; Belharouak, I.; Buettner-Garrett, J.; Chen, Z.; Daniel, C.; Doeff, M.; Dudney, N. J. Challenges for and pathways toward Li-metal-based all-solid-state batteries. ACS Energy Lett. 2021, 1399-1404.

(2) Thangadurai, V.; Narayanan, S.; Pinzaru, D. Garnet-type solidstate fast $\mathrm{Li}$ ion conductors for $\mathrm{Li}$ batteries: critical review. Chem. Soc. Rev. 2014, 43 (13), 4714-4727. 
(3) Murugan, R.; Thangadurai, V.; Weppner, W. Fast lithium ion conduction in garnet-type $\mathrm{Li}_{7} \mathrm{La}_{3} \mathrm{Zr}_{2} \mathrm{O}_{12}$. Angew. Chem., Int. Ed. 2007, 46 (41), 7778-7781.

(4) Ohta, S.; Kobayashi, T.; Asaoka, T. High lithium ionic conductivity in the garnet-type oxide $\mathrm{Li}_{7-\mathrm{X}} \mathrm{La}_{3}\left(\mathrm{Zr}_{2-\mathrm{X}}, \mathrm{Nb}_{\mathrm{X}}\right) \mathrm{O}_{12}(\mathrm{X}=$ 0-2). J. Power Sources 2011, 196 (6), 3342-3345.

(5) Allen, J. L.; Wolfenstine, J.; Rangasamy, E.; Sakamoto, J. Effect of substitution $(\mathrm{Ta}, \mathrm{Al}, \mathrm{Ga})$ on the conductivity of $\mathrm{Li}_{7} \mathrm{La}_{3} \mathrm{Zr}_{2} \mathrm{O}_{12}$. J. Power Sources 2012, 206, 315-319.

(6) Ohta, S.; Kihira, Y.; Asaoka, T. Spontaneous formation of a core-shell structure by a lithium ion conductive garnet-type oxide electrolyte for co-sintering with the cathode. J. Mater. Chem. A 2021, 9, 3353-3359.

(7) Buschmann, H.; Berendts, S.; Mogwitz, B.; Janek, J. Lithium metal electrode kinetics and ionic conductivity of the solid lithium ion conductors " $\mathrm{Li}_{7} \mathrm{La}_{3} \mathrm{Zr}_{2} \mathrm{O}_{12}$ " and $\mathrm{Li}_{7-x} \mathrm{La}_{3} \mathrm{Zr}_{2-x} \mathrm{Ta}_{\mathrm{x}} \mathrm{O}_{12}$ with garnet-type structure. J. Power Sources 2012, 206, 236-244.

(8) Buschmann, H.; Dölle, J.; Berendts, S.; Kuhn, A.; Bottke, P.; Wilkening, M.; Heitjans, P.; Senyshyn, A.; Ehrenberg, H.; Lotnyk, A.; et al. Structure and dynamics of the fast lithium ion conductor " $\mathrm{Li}_{7} \mathrm{La}_{3} \mathrm{Zr}_{2} \mathrm{O}_{12}$. Phys. Chem. Chem. Phys. 2011, 13 (43), 19378-19392.

(9) Kanno, R.; Murayama, M. Lithium ionic conductor thioLISICON: The $\mathrm{Li}_{2} \mathrm{~S}-\mathrm{GeS}_{2}-\mathrm{P}_{2} \mathrm{~S}_{5}$ system. J. Electrochem. Soc. 2001, 148 (7), A742.

(10) Murayama, M.; Sonoyama, N.; Yamada, A.; Kanno, R. Material design of new lithium ionic conductor, thio-LISICON, in the $\mathrm{Li}_{2} \mathrm{~S}-$ $\mathrm{P}_{2} \mathrm{~S}_{5}$ system. Solid State Ionics 2004, 170 (3), 173-180.

(11) Kamaya, N.; Homma, K.; Yamakawa, Y.; Hirayama, M.; Kanno, R.; Yonemura, M.; Kamiyama, T.; Kato, Y.; Hama, S.; Kawamoto, K.; Mitsui, A. A lithium superionic conductor. Nat. Mater. 2011, 10 (9), 682-686.

(12) Hayashi, A.; Hama, S.; Morimoto, H.; Tatsumisago, M.; Minami, T. Preparation of $\mathrm{Li}_{2} \mathrm{~S}-\mathrm{P}_{2} \mathrm{~S}_{5}$ amorphous solid electrolytes by mechanical milling. J. Am. Ceram. Soc. 2001, 84 (2), 477-79.

(13) Seino, Y.; Ota, T.; Takada, K.; Hayashi, A.; Tatsumisago, M. A sulphide lithium super ion conductor is superior to liquid ion conductors for use in rechargeable batteries. Energy Environ. Sci. 2014, 7 (2), 627-631.

(14) Deiseroth, H.-J.; Kong, S.-T.; Eckert, H.; Vannahme, J.; Reiner, C.; Zaiß, T.; Schlosser, M. Li $\mathrm{PS}_{5} \mathrm{X}$ : A class of crystalline Li-rich solids with an unusually high Li+ mobility. Angew. Chem., Int. Ed. 2008, 47 (4), $755-758$.

(15) Rao, R. P.; Adams, S. Studies of lithium argyrodite solid electrolytes for all-solid-state batteries. Phys. Status Solidi A 2011, 208 (8), 1804-1807.

(16) Belous, A. G. Synthesis and electrophysical properties of novel lithium ion conducting oxides. Solid State Ionics 1996, 90 (1), 193196.

(17) Stramare, S.; Thangadurai, V.; Weppner, W. Lithium lanthanum titanates: a review. Chem. Mater. 2003, 15 (21), 39743990.

(18) Zhao, Y.; Daemen, L. L. Superionic conductivity in lithium-rich anti-perovskites. J. Am. Chem. Soc. 2012, 134 (36), 15042-15047.

(19) Taylor, N. J.; Stangeland-Molo, S.; Haslam, C. G.; Sharafi, A.; Thompson, T.; Wang, M.; Garcia-Mendez, R.; Sakamoto, J. Demonstration of high current densities and extended cycling in the garnet $\mathrm{Li}_{7} \mathrm{La}_{3} \mathrm{Zr}_{2} \mathrm{O}_{12}$ solid electrolyte. J. Power Sources 2018, 396, 314-318.

(20) Sharafi, A.; Haslam, C. G.; Kerns, R. D.; Wolfenstine, J.; Sakamoto, J. Controlling and correlating the effect of grain size with the mechanical and electrochemical properties of $\mathrm{Li}_{7} \mathrm{La}_{3} \mathrm{Zr}_{2} \mathrm{O}_{12}$ solidstate electrolyte. J. Mater. Chem. A 2017, 5 (40), 21491-21504.

(21) Afyon, S.; Kravchyk, K. V.; Wang, S.; Broek, J. v. d.; Hänsel, C.; Kovalenko, M. V.; Rupp, J. L. M. Building better all-solid-state batteries with Li-garnet solid electrolytes and metalloid anodes. J. Mater. Chem. A 2019, 7 (37), 21299-21308.

(22) Connell, J. G.; Fuchs, T.; Hartmann, H.; Krauskopf, T.; Zhu, Y.; Sann, J.; Garcia-Mendez, R.; Sakamoto, J.; Tepavcevic, S.; Janek, J.
Kinetic versus thermodynamic stability of LLZO in contact with lithium Metal. Chem. Mater. 2020, 32 (23), 10207-10215.

(23) Zhu, Y.; Connell, J. G.; Tepavcevic, S.; Zapol, P.; GarciaMendez, R.; Taylor, N. J.; Sakamoto, J.; Ingram, B. J.; Curtiss, L. A.; Freeland, J. W.; Fong, D. D.; Markovic, N. M.; et al. Dopantdependent stability of garnet solid electrolyte interfaces with lithium metal. Adv. Energy Mater. 2019, 9 (12), 1803440.

(24) Rangasamy, E.; Wolfenstine, J.; Sakamoto, J. The role of Al and $\mathrm{Li}$ concentration on the formation of cubic garnet solid electrolyte of nominal composition $\mathrm{Li}_{7} \mathrm{La}_{3} \mathrm{Zr}_{2} \mathrm{O}_{12}$. Solid State Ionics 2012, 206, 2832.

(25) Thangadurai, V.; Pinzaru, D.; Narayanan, S.; Baral, A. K. Fast solid-state $\mathrm{Li}$ ion conducting garnet-type structure metal oxides for energy storage. J. Phys. Chem. Lett. 2015, 6 (2), 292-299.

(26) Wang, C.; Fu, K.; Kammampata, S. P.; McOwen, D. W.; Samson, A. J.; Zhang, L.; Hitz, G. T.; Nolan, A. M.; Wachsman, E. D.; Mo, Y.; et al. Garnet-type solid-state electrolytes: materials, interfaces, and batteries. Chem. Rev. 2020, 120 (10), 4257-4300.

(27) Zhu, Y.; He, X.; Mo, Y. Origin of outstanding stability in the lithium solid electrolyte materials: insights from thermodynamic analyses based on first-principles calculations. ACS Appl. Mater. Interfaces 2015, 7 (42), 23685-23693.

(28) Xiao, Y.; Wang, Y.; Bo, S.-H.; Kim, J. C.; Miara, L. J.; Ceder, G. Understanding interface stability in solid-state batteries. Nat. Rev. Mater. 2020, 5 (2), 105-126.

(29) Kim, K. J.; Balaish, M.; Wadaguchi, M.; Kong, L.; Rupp, J. L. M. Solid-state $\mathrm{Li}-$ metal batteries: Challenges and horizons of oxide and sulfide solid electrolytes and their interfaces. Adv. Energy Mater. 2021, 11 (1), 2002689.

(30) Zhao, N.; Khokhar, W.; Bi, Z.; Shi, C.; Guo, X.; Fan, L.-Z.; Nan, C.-W. Solid garnet batteries. Joule 2019, 3 (5), 1190-1199.

(31) Shen, X.; Zhang, Q.; Ning, T.; Liu, T.; Luo, Y.; He, X.; Luo, Z.; $\mathrm{Lu}, \mathrm{A}$. Critical challenges and progress of solid garnet electrolytes for all-solid-state batteries. Mater. Today Chem. 2020, 18, 100368.

(32) Duan, H.; Oluwatemitope, F.; Wu, S.; Zheng, H.; Zou, Y.; Li, G.; Wu, Y.; Liu, H. Li/Garnet interface optimization: An overview. ACS Appl. Mater. Interfaces 2020, 12 (47), 52271-52284.

(33) Kim, A.; Woo, S.; Kang, M.; Park, H.; Kang, B. Research progresses of garnet-type solid electrolytes for developing all-solidstate Li batteries. Front. Chem. 2020, 8, 468.

(34) Samson, A. J.; Hofstetter, K.; Bag, S.; Thangadurai, V. A bird'seye view of $\mathrm{Li}$-stuffed garnet-type $\mathrm{Li}_{7} \mathrm{La}_{3} \mathrm{Zr}_{2} \mathrm{O}_{12}$ ceramic electrolytes for advanced all-solid-state Li batteries. Energy Environ. Sci. 2019, 12 (10), 2957-2975.

(35) Liu, Q.; Geng, Z.; Han, C.; Fu, Y.; Li, S.; He, Y.-b.; Kang, F.; Li, B. Challenges and perspectives of garnet solid electrolytes for all solidstate lithium batteries. J. Power Sources 2018, 389, 120-134.

(36) Xu, L.; Li, J.; Deng, W.; Shuai, H.; Li, S.; Xu, Z.; Li, J.; Hou, H.; Peng, H.; Zou, G.; Ji, X. Garnet solid electrolyte for advanced allsolid-state Li batteries. Adv. Energy Mater. 2021, 11 (2), 2000648.

(37) Fu, Z.; Zhang, L.; Gritton, J. E.; Godbey, G.; Hamann, T.; Gong, Y.; McOwen, D.; Wachsman, E. Probing the mechanical properties of a doped $\mathrm{Li}_{7} \mathrm{La}_{3} \mathrm{Zr}_{2} \mathrm{O}_{12}$ garnet thin electrolyte for solidstate batteries. ACS Appl. Mater. Interfaces 2020, 12 (22), 2469324700.

(38) Kerman, K.; Luntz, A.; Viswanathan, V.; Chiang, Y.-M.; Chen, Z. Review-practical challenges hindering the development of solid state Li ion batteries. J. Electrochem. Soc. 2017, 164 (7), A1731A1744.

(39) Yi, E.; Wang, W.; Kieffer, J.; Laine, R. M. Flame made nanoparticles permit processing of dense, flexible, $\mathrm{Li}^{+}$conducting ceramic electrolyte thin films of cubic- $\mathrm{Li}_{7} \mathrm{La}_{3} \mathrm{Zr}_{2} \mathrm{O}_{12}$ (c-LLZO). J. Mater. Chem. A 2016, 4 (33), 12947-12954.

(40) Yi, E.; Wang, W.; Kieffer, J.; Laine, R. M. Key parameters governing the densification of cubic- $\mathrm{Li}_{7} \mathrm{La}_{3} \mathrm{Zr}_{2} \mathrm{O}_{12} \mathrm{Li}^{+}$conductors. $J$. Power Sources 2017, 352, 156-164.

(41) Golozar, M.; Paolella, A.; Demers, H.; Savoie, S.; Girard, G.; Delaporte, N.; Gauvin, R.; Guerfi, A.; Lorrmann, H.; Zaghib, K. 
Direct observation of lithium metal dendrites with ceramic solid electrolyte. Sci. Rep. 2020, 10 (1), 18410.

(42) Cao, D.; Sun, X.; Li, Q.; Natan, A.; Xiang, P.; Zhu, H. Lithium dendrite in all-solid-state batteries: growth mechanisms, suppression strategies, and characterizations. Matter 2020, 3 (1), 57-94.

(43) Krauskopf, T.; Dippel, R.; Hartmann, H.; Peppler, K.; Mogwitz, B.; Richter, F. H.; Zeier, W. G.; Janek, J. Lithium-metal growth kinetics on LLZO garnet-type solid electrolytes. Joule 2019, 3 (8), 2030-2049.

(44) Kim, K. J.; Rupp, J. L. M. All ceramic cathode composite design and manufacturing towards low interfacial resistance for garnet-based solid-state lithium batteries. Energy Environ. Sci. 2020, 13 (12), 49304945.

(45) Han, F.; Yue, J.; Chen, C.; Zhao, N.; Fan, X.; Ma, Z.; Gao, T.; Wang, F.; Guo, X.; Wang, C. Interphase engineering enabled allceramic lithium battery. Joule 2018, 2 (3), 497-508.

(46) Liu, T.; Ren, Y.; Shen, Y.; Zhao, S.-X.; Lin, Y.; Nan, C.-W. Achieving high capacity in bulk-type solid-state lithium ion battery based on $\mathrm{Li}_{6.75} \mathrm{La}_{3} \mathrm{Zr}_{1.75} \mathrm{Ta}_{0.25} \mathrm{O}_{12}$ electrolyte: Interfacial resistance. J. Power Sources 2016, 324, 349-357.

(47) Liu, T.; Zhang, Y.; Zhang, X.; Wang, L.; Zhao, S.-X.; Lin, Y.-H.; Shen, Y.; Luo, J.; Li, L.; Nan, C.-W. Enhanced electrochemical performance of bulk type oxide ceramic lithium batteries enabled by interface modification. J. Mater. Chem. A 2018, 6 (11), 4649-4657.

(48) Ren, Y.; Liu, T.; Shen, Y.; Lin, Y.; Nan, C.-W. Garnet-type oxide electrolyte with novel porous-dense bilayer configuration for rechargeable all-solid-state lithium batteries. Ionics 2017, 23 (9), 2521-2527.

(49) Kato, T.; Iwasaki, S.; Ishii, Y.; Motoyama, M.; West, W. C.; Yamamoto, Y.; Iriyama, Y. Preparation of thick-film electrode-solid electrolyte composites on $\mathrm{Li}_{7} \mathrm{La}_{3} \mathrm{Zr}_{2} \mathrm{O}_{12}$ and their electrochemical properties. J. Power Sources 2016, 303, 65-72.

(50) Ohta, S.; Komagata, S.; Seki, J.; Saeki, T.; Morishita, S.; Asaoka, T. All-solid-state lithium ion battery using garnet-type oxide and $\mathrm{Li}_{3} \mathrm{BO}_{3}$ solid electrolytes fabricated by screen-printing. J. Power Sources 2013, 238, 53-56.

(51) Liu, T.; Zhang, Y.; Chen, R.; Zhao, S.-X.; Lin, Y.; Nan, C.-W.; Shen, Y. Non-successive degradation in bulk-type all-solid-state lithium battery with rigid interfacial contact. Electrochem. Commun. 2017, 79, 1-4.

(52) Inada, R.; Yasuda, S.; Tojo, M.; Tsuritani, K.; Tojo, T.; Sakurai, Y. Development of lithium-stuffed garnet-type oxide solid electrolytes with high ionic conductivity for application to all-solid-state batteries. Front. Energy Res. 2016, 4, 28.

(53) Wang, M. J.; Choudhury, R.; Sakamoto, J. Characterizing the Li-solid-electrolyte interface dynamics as a function of stack pressure and current density. Joule 2019, 3 (9), 2165-2178.

(54) Zhang, X.; Wang, Q. J.; Harrison, K. L.; Roberts, S. A.; Harris, S. J. Pressure-driven interface evolution in solid-state lithium metal batteries. Cell Rep. Phys. Sci. 2020, 1 (2), 100012.

(55) Krauskopf, T.; Richter, F. H.; Zeier, W. G.; Janek, J. Physicochemical concepts of the lithium metal anode in solid-state batteries. Chem. Rev. 2020, 120 (15), 7745-7794.

(56) Krauskopf, T.; Hartmann, H.; Zeier, W. G.; Janek, J. Toward a fundamental understanding of the lithium metal anode in solid-state batteries - an electrochemo-mechanical study on the garnet-type solid electrolyte $\mathrm{Li}_{6.25} \mathrm{Al}_{0.25} \mathrm{La}_{3} \mathrm{Zr}_{2} \mathrm{O}_{12}$. ACS Appl. Mater. Interfaces 2019, 11 (15), 14463-14477.

(57) Zhang, Z.; Shao, Y.; Lotsch, B.; Hu, Y.-S.; Li, H.; Janek, J.; Nazar, L. F.; Nan, C.-W.; Maier, J.; Armand, M.; Chen, L. New horizons for inorganic solid state ion conductors. Energy Environ. Sci. 2018, 11 (8), 1945-1976.

(58) Famprikis, T.; Canepa, P.; Dawson, J. A.; Islam, M. S.; Masquelier, C. Fundamentals of inorganic solid-state electrolytes for batteries. Nat. Mater. 2019, 18 (12), 1278-1291.

(59) Schnell, J.; Günther, T.; Knoche, T.; Vieider, C.; Köhler, L.; Just, A.; Keller, M.; Passerini, S.; Reinhart, G. All-solid-state lithiumion and lithium metal batteries - paving the way to large-scale production. J. Power Sources 2018, 382, 160-175.
(60) Jung, K.-N.; Shin, H.-S.; Park, M.-S.; Lee, J.-W. Solid-state lithium batteries: Bipolar design, fabrication, and electrochemistry. ChemElectroChem 2019, 6 (15), 3842-3859. 